УДК 372.893

DOI: $10.37026 / 2520-6427-2019-100-4-104-107$
Тетяна СЕРДЮК, кандидат педагогічних наук, викладачка Мелітопольського промислово-економічного коледжу Запорізької області

\title{
ФОРМУВАННЯ СИСТЕМНОГО МИСЛЕННЯ ЗДОБУВАЧІВ ОСВІТИ НА ЗАНЯТТЯХ 3 ІСТОРІЇ УКРАЇНИ ЗА ДОПОМОГОЮ НАОЧНИХ ЗАСОБІВ НАВЧАННЯ
}

У статті окреслено проблеми формування та розвитку системного мислення в суб'єктів пізнання в прочесі вивчення історії Украӥни. Представлено основні характеристики системного мислення як цілісного процесу, спрямованого на формування єдиної картини світу. Наведено приклади застосування авторських наочних засобів навчання, завдяки яким історичний прочес представлено як єдину систему 3 притаманними їи закономірностями.

Ключові слова: система, системне мислення, наочні засоби навчання, історія України.

В статье обозначены проблемы формирования и развития системного мышления у субъектов познания в прочессе изучения истории Украины. Представлены основные характеристики системного мышиления как иелостного прочесса, направленного на формирование единой картины мира. Приведень примеры применения авторских наглядных средств обучения, благодаря которым исторический прочесс представлен как единая система, которой присущии закономерности.

Ключевые слова: система, системное мылиление, наглядные средства обучения, история Украины.

In the article the peculiarities of the use of visual aids in the lessons of history of Ukraine with the purpose of formation and development of students of system thinking are analyzed.

A system is a category that means an entity organized as a whole, where the bonding energy between the elements of this object exceeds the energy of their bonding with the elements of other objects.

In the process of system thinking, the subject views the object of study as a system, distinguishing in it properties, relationships, laws, and more. System thinking allows to synthesize individual factual knowledge, phenomena, objects, processes, own experience into a single holistic vision of the world.

The question arises about directions and methods of formation of system thinking in the educational process.
Based on our own pedagogical experience in teaching history in college, we can argue that the prevailing discrete, fragmented historical thinking in the young students. First of all, this, in our opinion, is an acute problem in studying the history of Ukraine.

One way to overcome this problem is to use visual aids in the educational process.

The use of clarity is one of the key principles of the pedagogical process. To teach the disciplines of the humanities cycle, the use of visual visual materials is essential. This is based both on the specifics of the training material and on the peculiarities of human perception: vision is the main way of obtaining information.

We made an attempt to visualize all the educational material on the history of Ukraine as a single system. During the work of creating a visual reflection of the course "History of Ukraine» as a system for the purpose of forming systemic thinking among students, we have structured the corresponding educational material.

Using such systematic visual material allows you to expand the range of educational activities in the classroom, offer tasks to determine the parallels between different periods, analyze the impact of events over a period of time, identify certain trends in individual periods, generalize their own understanding of the historical process and more.

Key words: system, systemic thinking, visual aids, history of Ukraine.

Постановка проблеми. Поняття «система» $є$ одним із ключових у нашому житті. Зокрема, людина не лише $\epsilon$ трирівневою системою, 3 притаманними їй соматичним, психічним та духовним рівнями, а й складовою інших систем. Таким чином, суб'єкт розуміє середовище як ціле, що складається 3 певних частин. Зважаючи на це, кожен компонент системи є іншою системою, яка не лише є підсистемою стосовно першої, а й надсистемою для інших своїх компонентів. Отже, формування в молоді системного підходу як одного 3 методів мислення можемо розглядати як одне $з$ пріоритетних завдань сучасної освіти. 
Аналіз наукових досліджень і публікацій. Сьогодні серед української педагогічної спільноти точаться жваві дискусії щодо проблеми системного підходу в освіті, якій низка вчених (В. Бондар, С. Гончаренко, І. Малафіїк, Є. Павлютенков, В. Приходько, Т. Сорочан Ю. Шабанова та ін.) присвятила свої наукові розвідки. Питання формування та розвитку системного мислення розкрито в працях Л. Шрагіної, О. Яковенко, Дж. О’Коннора, О. Решетової, І. Макдермотта, Ф. Капри, Н. Навоєвої та ін.

Однак варто зауважити, що в сучасній науково-методичні літературі недостатньо уваги приділяється практичним методам і прийомам, спрямованим на формування системного мислення у процесі викладання навчальних дисциплін, зокрема й історії України, що й послужило написанню нами даної статті.

Мета статті - на конкретних прикладах продемонструвати ефективність застосування наочних засобів навчання з метою формування системного мислення на заняттях з історії України.

Виклад основного матеріалу. Система - це категорія, під якою розуміємо цілісний об'єкт, де енергія зв'язків між елементами даного об'єкта значно перевищує енергію їх зв'язків з елементами інших об'єктів. У численних трактуваннях термінів «системність» та "система» можемо виокремити два підходи, а саме:

1. Системність інтегрується як фундаментальна властивість об' єктів пізнання. Зважаючи на це, завданням системного дослідження є вивчення специфічно системних властивостей об'єкта, зокрема виокремлення в ньому певних елементів, зв'язків, структур тощо. За такого підходу система розглядається як об'єкт, якому притаманні певні закономірності.

2. Система (із грецькк. ельбтй ү (епісте) - знання) розглядається як епістемологічний продукт, який хоч і позбавлений конкретного природного змісту, проте задає специфічний спосіб організації знання та мислення.

Основними змістовими ознаками системи є такі, що характеризують:

- внутрішній стан системи (основні складові, відношення, властивості та канали зв'язку, особливості побудови та ін.);

- специфічні системні властивості (ізоляція, взаємодія, інтеграція, диференціація, централізація, децентралізація, цілісність, стабільність, зворотний зв'язок, регуляція, управління, конкуренція та ін.);

- поведінку системи (середовище, діяльність, особливості функціонування, зміни, адаптація, розвиток (простий і структурний), еволюція, генезис, цілеспрямованість та ін.) [4, с. 115].

Розуміючи оточуючу реальність як ієрархію систем, усвідомлюємо, що прагнення суб'єкта іiі зрозуміти вимагає системного мислення як цілісної складової, що грунтується на врахуванні зв'язків між різними елементами системи та розумінні значущості цих зв'язків. До загальних прийомів активізації системного мислення відносять:

- узагальнення - вирішення більш глобальної проблеми, до складу якої входить похідна;

- деталізацію - звернення уваги на «дрібниці», певні складові проблеми;

- пошук аналогій - аналіз проблеми з різних сторін, знаходження правильного рішення, посилаючись на певні аналогії, наявні в різних галузях знань [6, с. 56].
У процесі системного мислення суб' єкт розглядає об'єкт дослідження як систему, виокремлюючи в ньому властивості, відносини, закони тощо. Системне мислення дозволяє суб'єкту встановлювати взаємозв'язки між елементами, виявляти закономірності процесів, що відбуваються в системі, їх взаємодію, прогнозувати їх розвиток, вбачати цілісність у взаємодії елементів. Об'єкт дослідження при цьому розглядається як складне утворення, специфіка якого визначається не так елементами, як характером відношень і зв'язків між ними.

Зауважимо, що головна особливість системних зв'язків - здатність упорядкувати будь-які розрізнені частини в одне ціле, тобто наявність певної структури як внутрішньої впорядкованості, організованості системи. Оскільки внаслідок впливу на будь-який (навіть незначний) елемент системи змінюється вся система загалом, системне мислення дає змогу виявляти зворотні зв'язки (навіть інколи відтерміновані в часі), що є результатом очікуваних змін.

Вивчення та аналіз низки систем допомагає розглянути об'єкт дослідження з різних сторін, на різних рівнях, моделюючи таким чином різні підходи щодо сприйняття реальності, що в кінцевому підсумку призводить до здатності здобувачів освіти створювати власні ментальні моделі, виходячи за межі особистих та суспільних стереотипів.

Таким чином, системне мислення дає змогу синтезувати окремі фактичні знання, явища, предмети, процеси, власний досвід в єдине цілісне бачення світу як інструмент упорядкування окремих результатів навчально-пізнавальної діяльності в ієрархізовану структуру з визначенням типів зв'язків та взаємовпливів. Здобувачі освіти заповнюють порожні комірки у матриці власного світогляду новими смислами з різних сфер людської культури, пов'язуючи їх 3 уже відомими їм типами діяльності. Таким чином, завдяки системному мисленню, замість хаотичного накопичення знань та вмінь із різних навчальних дисциплін, відбувається взаємопроникнення навчального матеріалу 3 різних дисциплін, створюються передумови для успішної діяльності на міждисциплінарних стиках [3, с. 36].

На підставі власного педагогічного досвіду викладання історії в Мелітопольському промисловоекономічному коледжі можемо стверджувати про переважання в сучасних молодих людей дискретного й фрагментарного історичного мислення. Зокрема, студенти у більшості випадків демонструють слабке розуміння цілісності, системності історичного процесу, єдності економічних, політичних, соціальних відносин, причино-наслідкових зв'язків між різними подіями, а більшість із них, на жаль, неспроможні на підставі знань про окремі історичні події, діяльність історичних постатей, розвиток регіонів сформувати уявлення про єдиний історичний простір. Саме це, на нашу думку, є неабиякою проблемою у вивченні історії України, вирішення якої вбачаємо передусім у використанні на заняттях наочних засобів навчання.

На власному прикладі переконалися, що використання наочностіє одниміз найважливіших дидактичних принципів, важливим компонентом формування інтересу до навчальної діяльності, коли більшість інформації студенти отримують через споглядання. 
У педагогіці розрізняють візуальну, аудіальну, кінестетичну наочність. При цьому візуальна наочність поділяється на образну (натуральні об'єкти, об'ємні, образотворчі (фото, малюнки), графічні (креслення, графіки) й умовні) та необразну (схеми, таблиці, формули тощо).

Застосування наочних засобів навчання дає змогу залучити до сприйняття та переробки інформації максимальну кількість органів чуття, що в кінцевому підсумку призводить до більш глибокого осмислення та кращого засвоєння навчального матеріалу. Так, наочність дозволяє створити в суб'єкта пізнання цілісний образ об'єкта, що вивчається. При цьому особлива роль відведена пам'яті, увазі та мисленню. Як наслідок - суб'єкт включається до активного пошуку: висуває гіпотези, перевіряє їх на достовірність, розрізняє предмети та явища, осмислює створюваний образ [2, с. 262-263]. Крім того, використання в освітньому процесі наочних матеріалів допомагає грунтовно аналізувати матеріал, засвоювати хронологію та поняття, встановлювати причинно-наслідкові зв'язки, доводити правильність суджень та робити відповідні висновки [5, с. 375].
Аналіз наукової та методичної літератури засвідчує, що увага науковців передусім зосереджується на реалізації принципу наочності при викладанні певних складових навчального матеріалу, як-от: окремих фактів, явищ, подій тощо. Проте, ставлячи за мету формування в суб'єктів пізнання системного мислення, варто пам'ятати про принцип системності й у ході використання наочних засобів навчання. Зокрема, нами було зроблено спробу наочно представити увесь навчальний матеріал з курсу «Історія України» як єдину систему.

Iз метою формування в студентів системного мислення відповідний навчальний матеріал було структуровано, а саме: виокремлено основні етапи історичного розвитку України; окреслено визначні події та дати; визначено видатних історичних діячів; розроблено граф-схеми для ілюстрації конкретних історичних процесів; підібрано відповідні цитати з історичних джерел, що характеризують певні історичні події, картини, портрети, світлини, карти зображення творів мистецтва, архітектури тощо (див. рис. 1, 2).

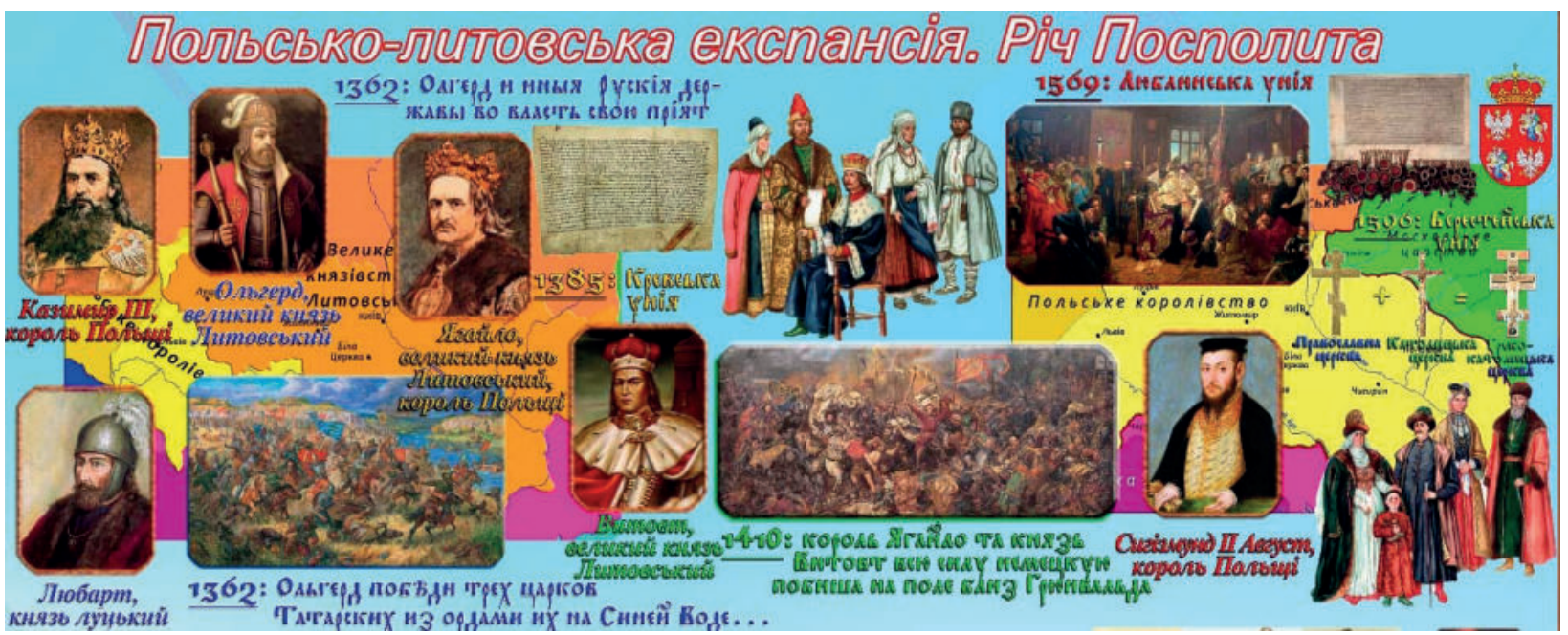

Рис. 1. Приклад наочного представлення навчального матеріалу з курсу «Історія Украйни» як єдиної системи. Тема «Польсько-литовська експансія. Утворення Речі Посполитої»

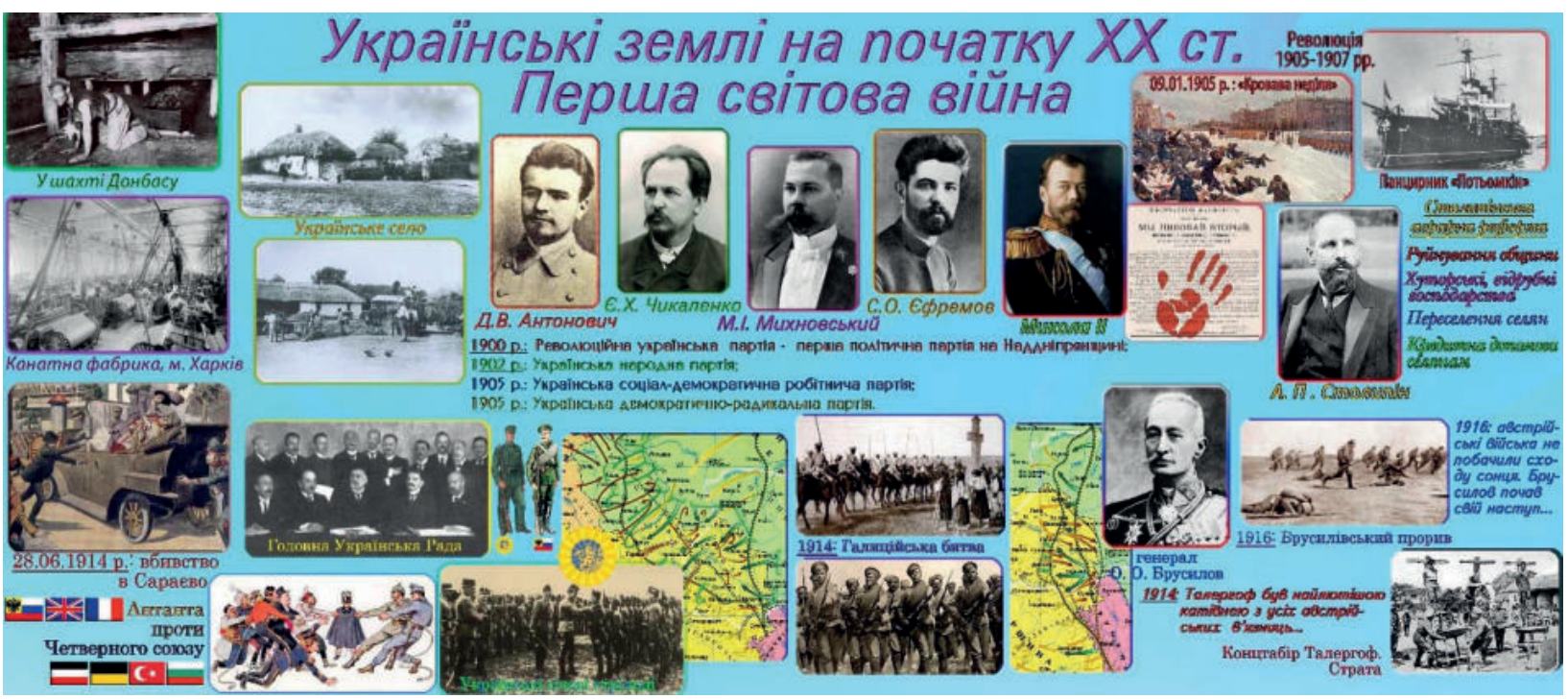

Рис. 2. Приклад наочного представлення навчального матеріалу з курсу «Історія Украӥни» як єдиної системи. Тема «Українські землі на початку ХХ століття» 
Представлений вище наочний матеріал було розташовано в хронологічній послідовності, зокрема зведено у п'ять настінних стендів загальною площею 7,5 м².

Основна мета створення таких стендів:

- наочно продемонструвати логіку історичного розвитку України, її етносів, державності, культури;

- окреслити вітчизняний історичний розвиток як певну цілісну систему;

- сформувати в студентів усвідомлення себе як складової історичного простору, носія певного історичного досвіду.

Використання даного матеріалу дає змогу розширити спектр навчальної діяльності, допомогти студентам у знаходженні певних тенденцій у розвитку відповідних історичних періодів, встановленні причинно-наслідкових зв'язків, узагальненні власного розуміння історичного процесу нашої держави тощо.

Висновки. Формування системного мислення в сучасної молоді - одне 3 ключових завдань на етапі реформування вітчизняної освіти. Особливо актуальним воно є в ході викладання історії України як потужного фактора впливу на підростаючу особистість. Застосування доречно підібраних та спеціально розроблених наочних засобів навчання, які грунтуються на представленні навчального матеріалу як єдиної системи, вважаємо неабияким ефективним інструментом у процесі інтелектуального та духовного становлення підростаючого покоління.

Подальші науково-методичні дослідження плануємо спрямувати на розробку комплексної методики викладання історичних дисциплін, що сприятиме формуванню в суб' єктів пізнання системного мислення.

\section{СПИСОК ВИКОРИСТАНОЇ ЛІТЕРАТУРИ}

1. Антонюк В. С. Біофізика і біомеханіка : підруч. / В. С. Антонюк, М. О. Бондаренко, В. А. Ващенко та ін. - К. : НТУУ «КПІ», 2012. - 344 с.

2. Багрій К. Л. Наочність у викладанні та іï значення в навчальному процесі / К. Л. Багрій // Вісник Чернівецького торговельно-економічного інституту. Економічні науки. - 2016. - Вип. 1 (61) C. 260-268.

3. Зубкова Л. М. Системне мислення як інтеграційний компонент формування цілісної особистості URL: https://seanewdim.com/uploads/3/4/5/1/34511564/ zubkova_1._m._systematic_thinking_as_an_integral_ component_in_forming_life_competence_of_a_person. pdf (дата звернення: 04.11.2019).

4. Паламарчук В. Ф. Як виростити інтелектуала / В. Ф. Паламарчук. - Тернопіль : Навчальна книга Богдан, 2000. - $152 \mathrm{c}$.

5. Сусоров В. Д. Психологічні основи наочності в курсі «Історія України» у вищій школі / В. Д. Сусоров // Південний архів. - 2008. - Вип. 28/29. - С. 374-378. - (Серія «Історичні науки»).

6. Яковенко О. В. Системне мислення як творчий підхід до вирішення проблем / О.В.Яковенко. URL: http://ekmair.ukma.edu.ua/bitstream/handle/ 123456789/6106/Yakovenko_Systemne_myslennya yak tvorchyy pidkhid do vyrishennya.PDF?sequence =1\&isAllowed=y (дата звернення: 04.11.2019).

Дата надходження до редакиії: 06.11.2019 p. 